\title{
PENGARUH SUKU BUNGA, PROSEDUR PELAYANAN DAN KECEPATAN PELAYANAN TERHADAP KEPERCAYAAN NASABAH DAN KEPUTUSAN PENGAMBILAN KREDIT PADA BRI DI WILAYAH SURAKARTA
}

\author{
Jarot Santosa \\ Sekolah Tinggi Ilmu Ekonomi Adi Unggul Bhirawa Surakarta \\ e-mail : jrtsnts@gmail.com \\ Denny Mahendra \\ Sekolah Tinggi Ilmu Ekonomi Adi Unggul Bhirawa Surakarta
}

\begin{abstract}
The purpose of this study is to find out and test the influence of interest rates, service procedures and the speed of service on customer trust and decision to take credit at BRI in the Surakarta Region. The population in this study is credit customers above Rp. 500,000,000.00 at BRI in the Surakarta Region with 880 customers. The sample in this study is $10 \%$ of the population that is equal to 88 customers, rounded up to 100 respondents in order to get better results. The analysis technique in this study uses the instrument test, $t$ test, $F$ test, test coefficient of determination and path analysis. The Hypothesis Test results are that interest rates have a significant effect on customer trust. Service procedures have a significant effect on customer trust. Service speed has no significant effect on customer trust. Interest rates have a significant effect on credit decision making. Service procedures have a significant effect on credit decision making. Service speed has a significant effect on credit decision making. Trust has a significant effect on credit decision making. The results of the F test can be summed up together with variable interest rates, service procedures, service speed, and trust influencing credit decision making. The results of the coefficient of determination show that $98.2 \%$ interest rates, service procedures and service speed influence the decision to take credit at BRI in the Surakarta region. The results of path analysis show that the direct effect of service speed on credit decision making is the most dominant influence in influencing credit decision making at BRI in the Surakarta region.
\end{abstract}

\begin{abstract}
ABSTRAK
Tujuan penelitian ini adalah untuk mengetahui dan menguji pengaruh suku bunga, prosedur pelayanan dan kecepatan pelayanan terhadap kepercayaan nasabah dan keputusan pengambilan kredit pada BRI di Wilayah Surakarta. Populasi dalam penelitian ini adalah nasabah kredit diatas Rp. 500.000.000,00 di BRI di Wilayah Surakarta sejumlah 880 nasabah. Sampel dalam penelitian ini adalah sebesar $10 \%$ dari populasi yaitu sebesar 88 nasabah, dibulatkan menjadi 100 responden agar mendapatkan hasil yang lebih baik. Teknik analisis dalam penelitian ini menggunakan uji instrumen, uji t, uji F, uji koefisien determinasi dan analisis jalur. Hasil Uji Hipotesis adalah suku bunga berpengaruh signifikan terhadap kepercayaan nasabah. Prosedur pelayanan berpengaruh signifikan terhadap kepercayaan nasabah. Kecepatan pelayanan berpengaruh tidak signifikan terhadap kepercayaan nasabah. Suku bunga berpengaruh signifikan terhadap keputusan pengambilan kredit. Prosedur pelayanan berpengaruh signifikan terhadap keputusan pengambilan kredit. Kecepatan pelayanan berpengaruh signifikan terhadap keputusan pengambilan kredit. Kepercayaan berpengaruh signifikan terhadap keputusan pengambilan kredit. Hasil uji F dapat
\end{abstract}


disimpulkan secara bersama-sama variabel suku bunga, prosedur pelayanan, kecepatan pelayanan, dan kepercayaan berpengaruh terhadap keputusan pengambilan kredit. Hasil koefisien determinasi menunjukkan sebesar 98,2\% suku bunga, prosedur pelayanan dan kecepatan pelayanan mempengaruhi keputusan pengambilan kredit di BRI di wilayah Surakarta. Hasil analisis jalur menunjukkan bahwa pengaruh langsung kecepatan pelayanan terhadap keputusan pengambilan kredit merupakan pengaruh paling dominan dalam mempengaruhi keputusan pengambilan kredit di BRI di wilayah Surakarta.

Kata Kunci : Suku Bunga, Prosedur Pelayanan, Kecepatan Pelayanan, Kepercayaan Nasabah, Keputusan Pengambilan Kredit

\section{PENDAHULUAN}

Organisasi yang bergerak dibidang jasa, merupakan salah satu dari sekian banyak organisasi yang tumbuh dan berkembang di Indonesia. Jasa perbankan merupakan bisnis yang berbasis pada asas kepercayaan yang menuntut perusahaan makin mengoptimalkan pelayanan kepada nasabah. Hal ini dilakukan agar kepercayaan nasabah tetap terjaga yang artinya nasabah merasa puas apabila kebutuhannya terpenuhi, puas karena pelayanan yang diberikan oleh BRI di Wilayah Surakarta.

Semakin maju perekonomian didalam suatu negara maka secara langsung akan semakin meningkat pula kebutuhan masyarakatnya. Hal ini dikarenakan harus mampu mengikuti situasi dan kondisi tertentu yang sedang terjadi. Tidak sedikit perusahaan yang memerlukan sumber-sumber dana dari luar perusahaan untuk memenuhi kebutuhan dalam menunjang kegiatan operasionalnya. Sumber dana yang berasal dari luar dapat diperoleh dengan mengambil kredit.

Dalam memenuhi kebutuhan finansialnya masyarakat dapat mengajukan permohonan kredit kepada bank dalam bentuk kredit investasi atau kredit modal kerja. Sementara bagi masyarakat umum yang mengalami kesulitan ekonomi karena banyaknya tuntutan kebutuhan yang harus dipenuhi maka dapat mengambil jenis kredit konsumtif. Kredit konsumtif adalah kredit yang dapat digunakan untuk dikonsumsi atau untuk kebutuhan pribadi.
Menurut Moh.Tjoekam (2009:45) kredit dalam arti umum meliputi commercial loan dan consumer's loan. Commercial loan merupakan kredit yang diberikan kepada seseorang atau badan usaha, sehingga kredit ini mampu memperbaiki atau mengembangkan kinerja (performance) usaha debitur, bahkan jika mungkin dapat menciptakan backward dan forward linkage dan seterusnya dapat membawa efek berganda yang bersifat positif (multiplier effect). Penggunaan jenis kredit ini adalah untuk usaha-usaha produktif (kredit investasidan kredit modal kerja), yang dapat mendukung sektor riil dalam kehidupan perekonomian masyarakat. Consumer's loan merupakan kredit yang diberikan bukan untuk kegiatan usaha yang produktif, tetapi untuk penggunaan yang bersifat konsumtif, namun mampu meningkatkan taraf hidup dan memperkuat daya beli si peminjam, yang secara tidak langsung mendorong pertumbuhan dan perkembangan sektor riil.

Bagi lembaga perbankan nasabah ibarat nafas yang sangat berpengaruh terhadap kelanjutan usaha suatu bank. Oleh karena itu, bank harus dapat mencari nasabah sebanyak-banyaknya agar dana yang terkumpul dari nasabah tersebut dapat diputar oleh bank yang nantinya disalurkan kembali kepada masyarakat yang membutuhkan bantuan bank. Menurut Tjiptono (2006:56) pengertian nasabah adalah setiap orang yang membeli dan menggunakan produk atau jasa 
perusahaan. Menurut Saladin (2014:43) nasabah adalah orang atau badan yang mempunyai rekening simpanan atau pinjaman pada bank.

Dalam kegiatan mengambil kredit nasabah banyak dipengaruhi oleh berbagai faktor baik itu faktor internal dan faktor eksternal. Kedua faktor tersebut samasama mempengaruhi keputusan nasabah dalam mengambil keputusan untuk melakukan pinjaman berupa kredit. Lebih lanjut Kotler (2006:78) menjelaskan bahwa yang mempengaruhi nasabah dalam mengambil suatu keputusan untuk mengambil kredit yaitu terdiri dari faktor suku bunga, jaminan, pelayanan, dan kebudayaan. Jenis kredit yang diberikan oleh BRI di Wilayah Surakarta diantaranya kredit Pegawai, Kredit Umum, Kredit Pasar \& Desa, Kredit Bidan, Kredit Perawat, Kredit Guru Bantu Kredit Kelompok / UMKM (Kelompok K3P, Kelompok KKPK, kelompok PKM, Kelompok PUNDI dan Kelompok Koperasi Murid)

Faktor lain yang dapat mempengaruhi keputusan pengambilan kredit adalah tingkat suku bunga. Suku bunga adalah harga yang ditawarkan atas dana yang akan dikucurkan ke debitur. Tak heran jika suku bunga menjadi variabel utama yang biasanya ditanyakan oleh calon debitur. Suku bunga yang murah tentu saja menjadi pilihan, di samping faktor lainnya. Namun calon debitur harus teliti karena suku bunga yang sama apabila sistem perhitungannya beda, maka kewajiban yang harus dibayarkan menjadi berbeda. Hal-hal yang terkait dengan suku bunga antara lain adalah: jangka waktu kredit, sistem angsuran, down payments, dan biaya-biaya yang harus ditanggung oleh debitur.

Faktor jaminan yang dimiliki calon debitur sangat penting bagi bank dan menjadi hal yang mempengaruhi layak tidaknya kredit. Ketika debitur sadar bahwa jaminan menjadi ketentuan dalam proses kredit, maka debitur dapat menilai apakah dirinya bankable atau belum.
Sementara bagi debitur yang memiliki jaminan yang cukup berharga maka prosentase kredit yang dapat dicairkan atas jaminan akan mempengaruhi pengambilan kredit (loan to value). Di samping mempertimbangkan keamanan atas aset yang menjadi jaminan kredit.

Hasil penelitian yang dilakukan oleh Satriyo Dan Saryadi, (2014), Budiarto (2014), Damar (2014) menunjukkan bahwa tingkat suku bunga berpengaruh signifikan terhadap keputusan pengambilan kredit. Sedangkan hasil penelitian yang dilakukan oleh Fajar Adhitya, (2015) menunjukkan bahwa tingkat suku bunga berpengaruh tidak signifikan terhadap keputusan pengambilan kredit.

Kesenjangan antara teori hubungan antara suku bunga dengan keputusan pengambilan kredit dengan temuan hasil penelitian (teori gap) dan kesenjangan antara temuan hasil penelitian (riset gap) telah menimbulkan rasa ingin tahu untuk mengkaji lebih mendalam hubungan ke dua variabel yaitu pengaruh antara suku bunga dengan keputusan pengambilan kredit merupakan arah pengaruh yang dikaji dalam penelitian ini.

Pelayanan bank menjadi faktor yang banyak berpengaruh. Layanan yang dimaksud bisa mencakup kecepatan proses pencairan, kemudahan prosedur, kesediaan membantu dan memberikan bimbingan, teknologi perbankan yang memudahkan pembayaran, kedekatan lokasi dengan usaha, sampai dengan layanan pick up service.

Teori Moh.Tjoekam (2009:45) di atas sesuai dengan fenomena atau keadaaan yang terjadi di BRI di Wilayah Surakarta bahwa nasabah yang ingin mengambil kredit sering kali yang ditanyakan pertama kali adalah suku Bunga yang ditawarkan oleh BRI di Wilayah Surakarta, selain itu faktor pelayanan juga menjadi salah satu prioritas nasabah BRI di Wilayah Surakarta, bahwa dengan pelayanan yang baik nasabah akan tertarik atau percaya untuk mengambil 
kredit di BRI di Wilayah Surakarta. Hal ini tentunya tidak lepas dari jaminan yang menjadi dasar berapa banyak jumlah kredit yang akan dicairkan.

Hasil penelitian yang dilakukan oleh Margaretha (2016), Fajar Kartika, (2016), Budiarto (2014), Damar (2014) menunjukkan bahwa prosedur pelayanan berpengaruh signifikan terhadap keputusan pengambilan kredit. Sedangkan hasil penelitian yang dilakukan oleh Nyoni Laksana, (2016), menunjukkan bahwa prosedur pelayanan berpengaruh tidak signifikan terhadap keputusan pengambilan kredit.

Kesenjangan antara teori hubungan antara prosedur pelayanan dengan keputusan pengambilan kredit dengan temuan hasil penelitian (teori gap) dan kesenjangan antara temuan hasil penelitian (riset gap) telah menimbulkan rasa ingin tahu untuk mengkaji lebih mendalam hubungan ke dua variabel yaitu pengaruh antara prosedur pelayanan dengan keputusan pengambilan kredit merupakan arah pengaruh yang dikaji dalam penelitian ini.

Faktor lain yang mempengaruhi keputusan pengambilan kredit adalah kecepatan pelayanan. Kecepatan pelayanan yaitu suatu kemampuan untuk pelayanan yang cepat (responsive). Pelayanan adalah suatu bagian atau urutan yang terjadi dalam interaksi langsung antara seseorang dengan orang lain atau mesin secara fisik dan menyediakan kepuasan pelanggan. Dalam kamus besar Bahasa Indonesia pelayanan adalah usaha melayani kebutuhan orang lain (Supriatna, 2010)

Hasil penelitian yang dilakukan oleh Margaretha (2016), menunjukkan bahwa kecepatan pelayanan berpengaruh signifikan terhadap keputusan pengambilan kredit. Sedangkan hasil penelitian yang dilakukan oleh Damar (2014) menunjukkan bahwa kecepatan pelayanan berpengaruh tidak signifikan terhadap keputusan pengambilan kredit.
Kesenjangan antara teori hubungan antara kecepatan pelayanan dengan keputusan pengambilan kredit dengan temuan hasil penelitian (teori gap) dan kesenjangan antara temuan hasil penelitian (riset gap) telah menimbulkan rasa ingin tahu untuk mengkaji lebih mendalam hubungan ke dua variabel yaitu pengaruh antara kecepatan pelayanan dengan keputusan pengambilan kredit merupakan arah pengaruh yang dikaji dalam penelitian ini.

Adapun permasalahan yang terjadi di BRI di Wilayah Surakarta dari tingkat suku bunga, sebenarnya tingkat suku bunga hampir sama dengan perbankan lainnya, misalnya tabungan Wajib adalah tabungan yang dihimpun dari para debitur pada setiap realisasi kredit. Jasa bunga yang diberikan sebesar $4 \%$ per tahun, Tabungan Harimas (Tabungan Harian Masyarakat) merupakan tabungan dengan bunga harian. Jasa bunga yang diberikan sebesar $6 \%$ per tahun. Sangat efektif bagi Wirausaha dan Tabungan SRIKANDI (Sarana Investasi Keluarga Mandiri) adalah tabungan berhadiah yang diundi sebanyak 1 (satu) kali dalam 1 (satu) tahun dengan hadiah-hadiah menarik. Jasa bunga yang diberikan kepada penabung sebesar $6 \%$ pertahun. akan tetapi dalam hal ini prosedur pelayanan perlu diperjelas kembali dan diinformasikan kepada nasabah secara jelas karena masih banyak nasabah yang bingung ketika akan memohon pelayanan, sehingga prosedur perlu dievaluasi selain itu kecepatan pelayanan juga perlu diperhatikan, misalnya terkadang ada nasabah yang tidak ingin antri terlalu lama, hal ini sebenarnya sudah sesuai dengan nomer urut yang telah diberikan, untuk mengantisapasi tersebut maka BRI di Wilayah Surakarta perlu mengevaluasi kinerja pegawai dalam segi pelayanan nasabah secara langsung.

Berangkat dari fenomena dan pemikiran di atas, maka diperlukan penelitian berkenaan dengan pengaruh sistem penyampaian jasa tehadap suku bunga, prosedur pelayanan 
dan kecepatan pelayanan terhadap kepercayaan nasabah dan keputusan

\section{METODE}

Penelitian ini dilakukan dengan mengambil lokasi penelitian pada BRI di Wilayah Surakarta. Variabel yang digunakan dalam penelitian ini terdiri dari variabel independen terdiri dari suku bunga $\left(\mathrm{X}_{1}\right)$, prosedur pelayanan $\left(\mathrm{X}_{2}\right)$, kecepatan pelayanan $\left(\mathrm{X}_{3}\right)$, sedangkan variabel intervening adalah kepercayaan nasabah dan variabel dependen adalah keputusan pengambilan kredit nasabah (Y).

Populasi dalam penelitian ini adalah nasabah kredit diatas Rp. $500.000 .000,00$ di BRI di Wilayah Surakarta sejumlah 880 nasabah. Sampel dalam penelitian ini adalah sebesar $10 \%$ dari populasi yaitu sebesar 88 nasabah, dibulatkan menjadi 100 responden agar mendapatkan hasil yang lebih baik.

\section{ANALISIS DAN PEMBAHASAN Hasil Uji Validitas dan Reliabilitas}

Hasil uji validitas dan reliabilitas menunjukkan bahwa semua item pertanyaan yang digunakan dalam penelitian ini adalah valid dan reliabel.

\section{Hasil Uji Linieritas}

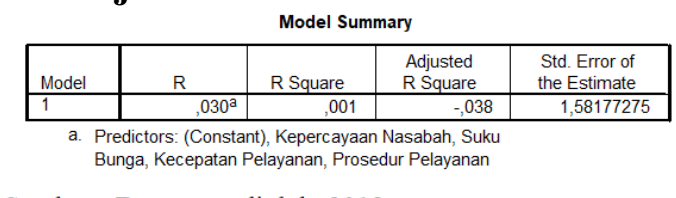

Sumber : Data yang diolah, 2018

Dari hasil uji linieritas menunjukkan nilai $\mathrm{R}^{2}$ sebesar 0,001 dengan jumlah sampel 108 , besarnya nilai $\mathrm{c}^{2}$ hitung $=100 \times 0,001$ $=0,100$ sedangkan nilai $\mathrm{c}^{2}$ tabel sebesar 129,56 Nilai $c^{2}$ hitung $<c^{2}$ tabel jadi dapat disimpulkan bahwa model yang benar adalah model linierier.

\section{Hasil Analisis Jalur \\ Pengaruh Langsung}

Pengaruh langsung adalah pengaruh dari satu variabel independen ke variabel pengambilan kredit nasabah,

Data yang digunakan adalah data primer dari responden terhadap jawaban kuesioner. Bentuk kuesioner berupa daftar pertanyaan yang disampaikan kepada nasabah BRI di Wilayah Surakarta. Kuesioner yang digunakan dalam penelitian ini dibagi menjadi dua bagian. Bagian pertama meliputi deskripsi responden yang diminta untuk mengisi kuesiner. Bagian kedua berisi item-item pertanyaan dari masing-masing variabel yang digunakan. Teknik analisis menggunakan analisis jalur. Dalam analisis jalur pengaruh variabel independen terhadap variabel dependen dapat berupa pengaruh langsung dan tidak langsung (direct dan indirect effect) atau dengan kata lain analisis jalur memperhitungkan adanya pengaruh langsung dan tidak langsung

dependen, tanpa melalui variabel dependen lainnya.

1. Pengaruh Suku bunga terhadap Keputusan pengambilan kredit

Berdasarkan hasil analisis diketahui suku bunga berpengaruh terhadap keputusan pengambilan kredit, dengan nilai koefisien sebesar 0,198.

2. Pengaruh Prosedur pelayanan terhadap keputusan pengambilan kredit.

Berdasarkan hasil analisis diketahui Prosedur pelayanan berpengaruh terhadap keputusan pengambilan kredit, dengan nilai koefisien sebesar 0,143.

3. Pengaruh Kecepatan pelayanan terhadap keputusan pengambilan kredit. Berdasarkan hasil analisis diketahui Kecepatan pelayanan berpengaruh terhadap keputusan pengambilan kredit, dengan nilai koefisien sebesar 0,351 .

\section{Pengaruh Tidak Langsung}

Pengaruh tidak langsung adalah situasi dimana variabel independen 
mempengaruhi variabel dependen melalui variabel lain yang disebut variabel intervening (Intermediary).

1. Pengaruh suku bunga terhadap keputusan pengambilan kredit pegawai melalui kepercayaan.

Berdasarkan hasil analisis diketahui pengaruh suku bunga terhadap keputusan pengambilan kredit melalui kepercayaan sebesar 0,132 lebih kecil dari pengaruh langsung.

2. Pengaruh prosedur pelayanan terhadap keputusan pengambilan kredit pegawai melalui kepercayaan.

Berdasarkan hasil analisis diketahui pengaruh prosedur pelayanan terhadap keputusan pengambilan kredit melalui kepercayaan sebesar 0,152 lebih besar dari pengaruh langsung.

3. Pengaruh kecepatan pelayanan terhadap keputusan pengambilan kredit pegawai melalui kepercayaan.

Berdasarkan hasil analisis diketahui pengaruh kecepatan pelayanan terhadap keputusan pengambilan kredit melalui kepercayaan sebesar 0,045 lebih kecil dari pengaruh langsung.

\section{Pengaruh Total}

1. Pengaruh suku bunga terhadap keputusan pengambilan kredit pegawai melalui kepercayaan, pengaruh total $0,198+0,132=0,330$.

2. Pengaruh prosedur pelayanan terhadap keputusan pengambilan kredit pegawai melalui kepercayaan, pengaruh total $0,143+0,152=0,295$.

3. Pengaruh kecepatan pelayanan terhadap keputusan pengambilan kredit pegawai melalui kepercayaan, pengaruh total $0,351+0,045=0,396$.

\section{Hasil Uji Hipotesis}

1. Suku bunga berpengaruh signifikan terhadap kepercayaan nasabah BRI di wilayah Surakarta, hal ini dapat dilihat dari nilai signifikansi yaitu $0,000<$ 0,05 .

2. Prosedur pelayanan berpengaruh signifikan terhadap kepercayaan nasabah BRI di wilayah Surakarta, hal ini dapat dilihat dari nilai signifikansi yaitu $0,000<0,05$.

3. Kecepatan pelayanan berpengaruh tidak signifikan terhadap kepercayaan nasabah BRI di wilayah Surakarta, hal ini dapat dilihat dari nilai signifikansi yaitu $0,155>0,05$.

4. Suku bunga berpengaruh signifikan terhadap keputusan pengambilan kredit BRI di wilayah Surakarta, hal ini dapat dilihat dari nilai signifikansi yaitu 0,003 $<0,05$.

5. Prosedur pelayanan berpengaruh signifikan terhadap keputusan pengambilan kredit BRI di wilayah Surakarta, hal ini dapat dilihat dari nilai signifikansi yaitu $0,022<0,05$.

6. Kecepatan pelayanan berpengaruh signifikan terhadap keputusan pengambilan kredit BRI di wilayah Surakarta, hal ini dapat dilihat dari nilai signifikansi yaitu $0,000<0,05$.

7. Kepercayaan berpengaruh signifikan terhadap keputusan pengambilan kredit BRI di wilayah Surakarta, hal ini dapat dilihat dari nilai signifikansi yaitu 0,000 $<0,05$.

\section{Hasil Analisis Koefisien Korelasi}

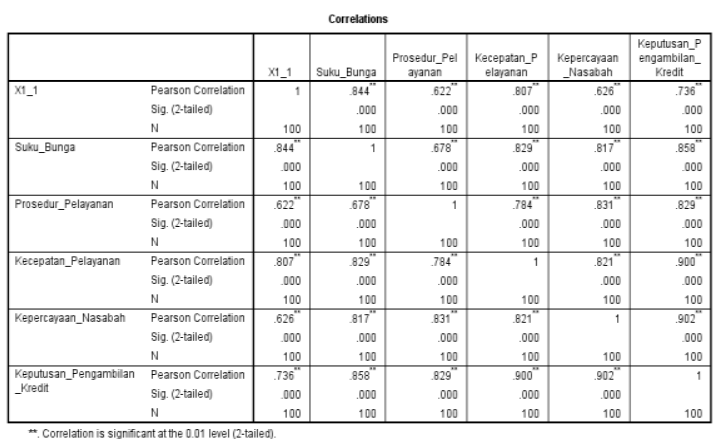

Sumber : Data yang diolah, 2018

Dari tabel di atas dapat diketahui hubungan atau korelasi antar variabel dapat dijelaskan sebagai berikut:

1. Suku bunga dengan kepercayaan nasabah BRI di wilayah Surakarta adalah 0,817. Dapat diartikan bahwa hubungan suku bunga dengan kepercayaan sangat kuat. 
2. Prosedur pelayanan dengan kepercayaan nasabah BRI di wilayah Surakarta adalah 0,831. Dapat diartikan bahwa hubungan Prosedur pelayanan dengan kepercayaan sangat kuat.

3. Kecepatan pelayanan dengan kepercayaan Nasabah BRI di wilayah Surakarta adalah 0,821. Dapat diartikan bahwa hubungan kecepatan pelayanan dengan kepercayaan sangat kuat.

4. Suku bunga dengan keputusan pengambilan kredit BRI di wilayah Surakarta adalah 0,858. Dapat diartikan bahwa hubungan suku bunga dengan keputusan pengambilan kredit sangat kuat.

5. Prosedur pelayanan dengan keputusan pengambilan kredit BRI di wilayah Surakarta adalah 0,829. Dapat diartikan bahwa hubungan prosedur pelayanan dengan keputusan pengambilan kredit sangat kuat.

6. Kecepatan pelayanan dengan keputusan pengambilan kredit BRI di wilayah Surakarta adalah 0,900. Dapat diartikan bahwa hubungan kecepatan pelayanan dengan keputusan pengambilan kredit sangat kuat.

7. Kepercayaan dengan keputusan pengambilan kredit BRI di wilayah Surakarta adalah 0,902. Dapat diartikan bahwa hubungan kepercayaan dengan keputusan pengambilan kredit sangat kuat.

\section{Pembahasan}

1. Pengaruh suku bunga terhadap keputusan pengambilan kredit melalui kepercayaan.

Hasil penelitian membuktikan bahwa dari analisis jalur ini menunjukkan bahwa penggunaan variabel intervening kepercayaan dalam rangka peningkatan keputusan pengambilan kredit, untuk variabel suku bunga adalah tidak efektif, karena pengaruh langsung menghasilkan pengaruh yang lebih besar, dari pada pengaruh tidak langsung. Hal ini berarti, untuk meningkatkan keputusan pengambilan kredit BRI di wilayah Surakarta sebaiknya meningkatkan suku bunga secara langsung agar dapat meningkatkan keputusan pengambilan kredit BRI di wilayah Surakarta.

$$
\text { Contoh hal yang dapat }
$$
dilakukan untuk meningkatkan suku bunga yaitu dengan cara melihat hasil nilai uji validitas nilai tertinggi dengan teknik one shot methods yaitu dengan langkah konkret yang dapat dilakukan adalah:

a. Adanya hubungan dengan nasabah yang potensial membuat BRI di wilayah Surakarta dapat memberikan suku bunga yang lebih rendah.

b. Jangka waktu pengambilan kredit membuat suku bunga yang diberikan nasabah BRI di wilayah Surakarta berbeda.

c. Keadaan ekonomi nasabah menjadi salah satu penentu tingkat suku bunga.

Dengan adanya upaya peningkatan suku bunga dan kepercayaan tersebut, maka keputusan pengambilan kredit BRI di wilayah Surakarta akan meningkat secara maksimal, sehingga target capaian BRI di wilayah Surakarta dapat tercapai.

2. Pengaruh Prosedur pelayanan terhadap keputusan pengambilan kredit melalui kepercayaan.

Hasil penelitian membuktikan bahwa dari analisis jalur ini menunjukkan bahwa penggunaan variabel intervening kepercayaan dalam rangka peningkatan keputusan pengambilan kredit, untuk variabel prosedur pelayanan adalah efektif, karena pengaruh langsung menghasilkan pengaruh yang lebih kecil, dari pada pengaruh tidak langsung. Hal ini mengidentifikasikan bahwa dalam mempengaruhi keputusan pengambilan kredit dapat meningkatkan prosedur pelayanan dengan melalui kepercayaan nasabah.

Contoh hal yang dapat meningkatkan kepercayaan nasabah 
misalnya dengan cara melihat hasil nilai uji validitas nilai tertinggi dengan teknik one shot methods yaitu dengan langkah konkret yang dapat dilakukan adalah:

a. Tingkat keterbukaan informasi mengenai prosedur pelayanan sudah tersusun secara rapi di BRI di Wilayah Surakarta.

b. Alur dalam proses pelayanan nasabah tidak berbelit-belit.

c. Tingkat kejelasan alur dalam prosedur pelayanan sudah dipenuhi oleh karyawan di BRI di Wilayah Surakarta.

Dengan adanya kepercayaan nasabah yang diberikan terhadap BRI, maka nasabah akan merasakan pelayanan yang disediakan oleh BRI di wilayah Surakarta dengan senang hati. Dengan hal tersebut, maka keputusan pengambilan kredit di BRI di wilayah Surakarta akan meningkat.

3. Pengaruh Kecepatan pelayanan terhadap keputusan pengambilan kredit melalui kepercayaan.

Hasil penelitian membuktikan bahwa dari analisis jalur ini menunjukkan bahwa penggunaan variabel intervening kepercayaan dalam rangka peningkatan keputusan pengambilan kredit, untuk variabel kecepatan pelayanan adalah tidak efektif, karena pengaruh langsung menghasilkan pengaruh yang lebih besar, dari pada pengaruh tidak langsung. Hal ini mengidentifikasikan bahwa dalam mempengaruhi keputusan pengambilan kredit lebih perlu melakukan peningkatan kecepatan pelayanan secara langsung.

Contoh hal yang dapat meningkatkan kecepatan pelayanan misalnya dengan cara melihat hasil nilai uji validitas nilai tertinggi dengan teknik one shot methods yaitu dengan langkah konkret yang dapat dilakukan adalah: a. Pegawai di BRI di wilayah Surakarta tanggap terhadap permasalahan nasabah.

b. BRI di wilayah Surakarta memiliki citra yang baik dalam melayani konsumen.

c. Pegawai di BRI di wilayah Surakarta cepat dalam menyelesaikan komplain.

Dengan adanya peningkatan kecepatan pelayanan yang baik, maka nasabah akan merasa nyaman saat bertransaksi di BRI di wilayah Surakarta. Dengan hal tersebut, keputusan pengambilan kredit di BRI di wilayah Surakarta akan meningkat.

\section{Kesimpulan}

\section{Hasil Uji Hipotesis}

Uji t persamaan 1:

1. Suku bunga berpengaruh signifikan terhadap kepercayaan nasabah BRI di wilayah Surakarta.

2. Prosedur pelayanan berpengaruh signifikan terhadap kepercayaan nasabah BRI di wilayah Surakarta.

3. Kecepatan pelayanan berpengaruh tidak signifikan terhadap kepercayaan nasabah BRI di wilayah Surakarta.

\section{Uji t persamaan 2:}

1. Suku bunga berpengaruh signifikan terhadap keputusan pengambilan kredit BRI di wilayah Surakarta.

2. Prosedur pelayanan berpengaruh signifikan terhadap keputusan pengambilan kredit BRI di wilayah Surakarta.

3. Kecepatan pelayanan berpengaruh signifikan terhadap keputusan pengambilan kredit BRI di wilayah Surakarta.

4. Kepercayaan berpengaruh signifikan terhadap keputusan pengambilan kredit BRI di wilayah Surakarta.

\section{Hasil uji F}

Hasil uji $F$ diketahui besarnya nilai $F$ sebesar 224.308 dan nilai signifikan 0,000 $<0,05$. Sehingga dapat disimpulkan secara bersama-sama variabel suku bunga, prosedur pelayanan, kecepatan pelayanan, 
dan kepercayaan berpengaruh terhadap keputusan pengambilan kredit BRI di wilayah Surakarta.

\section{Hasil uji Koefisien Determinasi}

Hasil tersebut dapat dijelaskan bahwa R2 total sebesar 0,982 dapat diartikan keputusan pengambilan kredit BRI di wilayah Surakarta dijelaskan oleh variabel suku bunga, prosedur pelayanan, kecepatan pelayanan dan kepercayaan sebesar $98,2 \%$ dan sisanya $1,8 \%$ dijelaskan

\section{KESIMPULAN DAN SARAN}

Berdasarkan hasil penelitian tersebut disarankan agar BRI di wilayah Surakarta dalam meningkatkan keputusan pengambilan kredit pegawai dapat melakukan hal-hal sebagai berikut:

1. Kecepatan pelayanan berpengaruh signifikan terhadap keputusan pengambilan kredit BRI di wilayah Surakarta. Contoh hal yang dapat meningkatkan kecepatan pelayanan misalnya dengan cara melihat hasil nilai uji validitas nilai tertinggi dengan teknik one shot methods yaitu dengan, langkah konkret yang dapat dilakukan adalah:

a. Pegawai di BRI di wilayah Surakarta tanggap terhadap permasalahan nasabah. Misalnya menanggapi keluhan nasabah dengan senang hati, memberikan solusi keluhan dengan baik dan melayani nasabah dengan penuh kesabaran.

b. BRI di wilayah Surakarta memiliki citra yang baik dalam melayani konsumen. Misalnya adanya pelayanan senyum, sapa dan salam, selain itu adanya pelayanan yang tidak pernah mengecewakan nasabah.

c. Pegawai di BRI di wilayah Surakarta cepat dalam menyelesaikan komplain. Misalnya komplain diselesaikan tidak kurang dari 24 jam, adanya kotak saran yang dapat digunakan untuk aduan demi perlayanan yang lebih baik dan variabel lain diluar model penelitian sebagai contoh: kualitas pelayanan, sarana prasarana dan promosi.

\section{Hasil Analisis Jalur}

Hasil analisis jalur menunjukkan bahwa pengaruh langsung kecepatan pelayanan terhadap keputusan pengambilan kredit merupakan pengaruh paling dominan dalam mempengaruhi keputusan pengambilan kredit di BRI di wilayah Surakarta.

adanya evaluasi setelah proses pelayanan.

2. Suku bunga berpengaruh signifikan terhadap keputusan pengambilan kredit BRI di wilayah Surakarta maka dalam meningkatkan keputusan pengambilan kredit perlu lebih meningkatkan suku bunga yaitu dengan cara melihat hasil nilai uji validitas nilai tertinggi dengan teknik one shot methods yaitu dengan langkah konkret yang dapat dilakukan adalah:

a. Adanya hubungan dengan nasabah yang potensial membuat BRI di wilayah Surakarta dapat memberikan suku bunga yang lebih rendah. Misalnya adanya penawaran suku bunga yang relevan, tingkat suku bunga dijelaskan secara transparan dan adanya kesepakatan dalam penentuan suku bunga.

b. Jangka waktu pengambilan kredit membuat suku bunga yang diberikan nasabah BRI di wilayah Surakarta berbeda. Misalnya jangka pengambilan kredit dengan jangka panjang dan jangka waktu pendek memperoleh tingkat suku bunga yang berbeda-beda.

c. Keadaan ekonomi nasabah menjadi salah satu penentu tingkat suku bunga. Misalnya memberikan fasilitas pinjaman khusus bagi yang memiliki ekonomi yang rendah dengan tingkat suku bunga yang rendah. 
Lingkup penelitian sebaiknya lebih luas lagi tidak hanya BRI di wilayah Surakarta tetapi lebih luas lagi atau dapat dilakukan di BRI di wilayah Jawa Tengah, agar hasil penelitian bisa dijadikan acuan penelitian yang lebih baik. 


\section{DAFTAR PUSTAKA}

Adi, Krismanto, 2007, "Analisis Faktor-faktor yang mempengaruhi loyalitas pasien Klinik Assalam Klaten”, Jurnal bisnis dan manajen Vol 4 No. 10 Pp. 123-236.

Anderson, E. and B. Weitz, 2003, "The Use of Pledges to Build and Sustain Commitment in Distribution Channel”, Journal of Marketing research 29 (1), p.18-34.

Arikunto, Suharsini, 2011. Prosedur Penelitian Suatu Pendekatan Praktek Edisi ketiga.

Barnes, James G.. 2007. Secret Of Customer Relationship Management. Andi : Yogyakarta.

Bernstein, Leopold A., John J. Wild, 2008. Financial Statement Analysis : Theory, Application, and Interpretation, 6th edition, Mc Grow-Hill.

Bolton, Ruth N and james H. Drew, 2001, "A Multi Stage Model of Customers Assessment of Service Quality and Value", Journal of Consumer Research, Januari, 1-9.

Bontis, Nick and Lorne D.Booker (2007), " The mediating effect of organizational reputation on customer loyalty and service recommendation in rumah sakiting industry", Journal Management Decion, Vol.45, No.9 p.1426-1445.

Brown, Stephen W., 2001, "A Multi Stage Model of Customers Assesment of Service Quality and Value", Journal of Marketing, April, pp. 92-98

Cronin J.Joseph Jr and Steven A. Taylor (2002), " Measuring Service Quality : A reexamination and extension", Journal of Marketing Vol. 56 (July) p.55 - 68

Carmel dan Tisher, 2004, Managing Human Resources: Productivity, Quality of Worklife and Profits, Singapore: Mc.Graw Hill International Editions.pp.68-75

Denhardt, Janer V, and Robert B. Denhardt. 2013. The New Public Service : Serving Not Steering. Armonk, N.Y : M.E.Sharpe.

Dharmesta, Basu Swastha (2009), “Loyalitas Nasabah : Sebuah kajian konseptual sebagai panduan bagi peneliti," Jurnal Ekonomi dan Bisnis Indonesia, Vol.14, No.3

Djarwanto dan Subagyo, Pangestu, 2011: Statistik Induktif, Edisi: 4, Yogyakarta: BPFE

Fajar Adhitya , 2015. Analisis Pengaruh Suku Bunga Kredit, Kualitas Pelayanan Inti, Kualitas Pelayanan Periferal Dan Kemampuan Tenaga Marketing Terhadap Keputusan Nasabah Dalam Pengambilan Kredit Di Bank Mandiri Unit Mikro Distrik Semarang. Tesis Magister Manajemen Universitas Diponegoro Semarang

Fisher dan Mankiw, Gregory N. 2013. Teori Makro Ekonomi. Terjemahan. Erlangga. Jakarta

Fornell, (2014), "The American Customer Satisfaction Index : Nature, Purpose, and Findings". Journal of Marketing, 60 (10). (7 - 18).

Ghozali, Imam, 2014. Aplikasi Analisis Multivariate Dengan Program SPSS 
Ghozali, Imam,2006. Analisis Regresi. Jakarta: Salemba Empat.

Gujarati, Damodar. 2005. Ekonometrika Dasar. Erlangga. Jakarta.

Griffin, Jill. 2012. Customer Loyalty, Menumbuhkan dan Mempertahankan Kesetiaan Pelanggan. Jakarta : Erlangga

Herbig, Paul, John Milewicz and Jim Golden,(2004). "A Model of Reputation Building and Destruction "Journal of Business Research. Vol.31, June 1994, No. 1 ; p.23-31.

Hirshman, 2012. Modul Analisa Data. Depok:FKM UI

Istijanto,2006,Riset Sumber Daya Manusia, Jakarta:PT. Gramedia Pustaka Utama

Juran, J.M., 2001, Quality Control Handbook, New York: Mc. Graw-Hill.

Kotler, Philip.(2013), Marketting Management, $11^{\text {th }}$ ed. Upper Saddle River, New Jersey : Prentice Hall, Inc

Kotler, Philip dan Amstrong, 2008, Manajemen Pemasaran, Edisi Millenium, Jakarta Prenhalindo

Kuncoro dan Adithya, 2010, Manajemen Perbankan (Teori dan Aplikasi), Edisi Pertama, Penerbit BPFE, Yogyakarta

Kusmayadi, Tatang, 2007, Pengaruh Relatinship Quality terhadap Loyalitas Nasabah Tabungan, STIE STAN Indonesia mandiri, Jepara

Liu, Tsung-Chi and Li Wei Wu (2007), "Customer retention and cross-buying in the rumah sakiting industry : An Integration of service attributes, satisfaction and trust" Journal of Financial Service Marketing, Vol.12 No.2 p.132-145.

Margaretha M, (2016), "Study Mengenai Loyalitas Pasien Divisi Asuransi Kumpulan AJB Bumi Putera 1912 (Studi khusus di Jawa Tengah)", Jurnal Sains Pemasaran Indonesia, Vol III, No.3, Desember 2004. (289-308)

Mahmudi. (2013). Manajemen Kinerja Sektor Publik. Yogyakarta: UPP AMP YKPN.

H, Moh, Tjoekam. (2009). Perkreditan Bisnis Inti Bank Komersial. Jakarta : PT Gramedia Pustaka Utama

Nachrowi, Djalal, 2006. Pendekatan Populer dan Praktis Ekonometrika Untuk Analisis Ekonomi dan keuangan. Jakarta: Lembaga penerbit Fakultas Ekonomi Universitas Indonesia.

Nyoni Laksana, 2016. Pengaruh Persepsi Harga, Prosedur Pelayanan dan Lokasi Terhadap Keputusan Nasabah Dalam Pengambilan Kredit Berjangka Pada Bank Jateng Cabang Semarang. Jurnal Bisnis Dan Pemasaran Vol. 3 No.4 Universitas Negeri Yogyakarta 
Oliver, Richard L. (2007), "Satisfaction : A Behavioral Perspective on the Customer", McGraw-Hill, New York, NY

Parasuraman, A.,A.Zeithmal, V.,\& L.Berry, L.2005” A conceptual Model of Service Quality and Its Implications for Future Research”, Journal of Marketing, Vol.49 (fall).

Peraturan Pemerintah Republik Indonesia No.25 tahun 1980 tentang perubahan atas Peraturan Pemerintah No. 26 tahun 1965 tentang Rumah sakit.

Prichard, mark P, 2010, "Analyzing the Commitment-Loyalty Link in Service Contexts", Journal of the Academy of Marketing Science 27 (3), p.333-348

Riduwan, 2005, Skala pengukuran Variabel-Variabel Penelitian, Cetakan Ketiga, Alfabeta, Bandung.

Samuelson, Paul A. dan William D. Nordhaus, 2005. Ilmu Makroekonomi. Edisi Ketujuhbelas. Jakarta: PT. Media Global Edukasi.

Saladin, Djaslim, 2004, Manajemen Pemasaran, Bandung: Linda Karya

Sarwono, Jonathan. 2010. Analisis Jalur Untuk Bisnis dengan SPSS. Penerbit Andi Offset:Yogyakarta.

Sekaran U, 2010. Research Methods For Business: A Skill Building Approach Singapore: John Willey dan Sonc, Inc

Selnes, Fred (2013), “An Examination of the effect of Product Performance on Brand Reputation, Satisfaction and Loyalty", European Journal of Marketing, 27 (9). (19$35)$.

Staraus dan Seidel, 2006. Macroeconomic Factor and The Empirical Content of The Arbitrage Pricing Theory in The Japanese Stock Market "The Journal of Finance.

Satriyo Dan Saryadi, 2014. Pengaruh Kualitas Pelayanan, Suku Bunga dan Lokasi Terhadap Keputusan Pengambilan Kredit Di PD BKK Pemalang. Diponegoro Journal of Social And Political Science Tahun 2014 http://ejournal-s1.undip.ac.id/index.php/

Solomon, Michael (2006), Consumer Behavion, $3^{\text {th }}$ edition, McGraw Hill.

Sugiyono, 2011. Metodologi Penelitian Bisnis, Cetakan Ketujuh, CV. Alpabeta, Bandung.

Supriatna Tjahja. 2010. Strategi Pembangunan dan Kemiskinan. Rineke Cipta. Jakarta

Sukirno. 2006. Makroekonomi. Teori Pengantar. Edisi Ketiga. PT. Raja Grasindo Perseda. Jakarta

Tjiptono, Fandi, 2006, Prinsip-prinsip Total Quality Service (TQS), Andi Offset, Yogyakarta. 
Tjiptono, Fandi, 2009.Manajemen Jasa, Andi Offset : Yogyakarta

Tjiptono, Fandi, 2012, Prinsip-prinsip Total Quality Service (TQS) , Andi Offset, Yogyakarta

Tronvoll, 2007, “An Assesment Of The Relationship Between Service Quality And Customer Satisfaction In The Formation Of Consumers Purchase Intention”, Journal Of Retailing. Vol 70, No.2, P.163

Wijaya, Serly dan Thio, Sienny, 2007, Implementasi Membership Card dan Pengaruhnya dalam Meningkatkan Loyalitas Pengunjung Restoran di Surabaya, Fakultas Ekonomi Universitas Kristen Petra.

Zeithaml, (2008), Consumer Perceptions of Price, "Quality, and Value : Means End Model and Synthesis of Evidence", Journal of Marketing, Vol 52, July, p.2-22 